\title{
Historical Considerations on the Ethics of Aging: Examples from the Sixteenth Century
}

The history of the ethics of aging is a complex and still neglected topic. From a scientific standpoint, we first need a definition: What does ethics mean today? (For instance, should we use a normative, consequentialist, or deontological ethics?) And what would an ethics of aging, specifically, be? Does such a specialized ethics exist, or should any ethics apply more generally to every period of life? Supposing we grant the existence of a special ethics for the elderly, should we distinguish between an ethics for the "young old" and another for the "very old"? What are the topics of this specialized "ethics" at present? Perhaps it is only once we have solved these problems that it will make sense to look backwards, asking how the ethics of aging was approached in the past.

Yet we could also proceed in the opposite direction. Instead of looking back, history could help us to look ahead. In this article, we use examples from the sixteenth century to observe what kind of moral questions were discussed in a gerontological context, and explore how these discussions were influenced by historical circumstance and the participants' professional backgrounds. (By focusing on moral questions, we avoid the term "ethics," which is anachronistic in premodern medicine, and even, to a certain degree, in early modern philosophy.) Secondly, we compare these findings with present ethical debates on old age (although necessarily relying on only a limited number of examples). This approach not only enables us to perceive similarities and differences, but to identify some necessary premises for a special ethics of aging.

\section{Cardano's teeth and their moral implications}

We start with a text by a sixteenth-century polymath who approached questions of aging in a remarkably detailed, plain-spoken way. The physician, mathematician, and philosopher Gerolamo Cardano was born in Pavia in 1501 and died in Rome in 1576 - a very old man, by the standards of his time (Siraisi 1997). A skilled observer, Cardano accurately listed the physical and mental effects of his own process of aging in his autobiography, De propria vita (Ch. 6, 46). We learn, among other things, how many teeth he lost, and when: until the age of 63 , he had still a full set, with one or two exceptions; by 75 , only "fourteen

Ә OpenAccess. (C) 2021 Daniel Schäfer, published by De Gruyter. (cc))BY-NC-ND This work is licensed under the Creative Commons Attribution-NonCommercial-NoDerivatives 4.0 International License. 
remained, in addition to a diseased one." He informs us that he suffered from stomach problems, a hernia, and itching, and complains above all about his inability to have sex with women (impotentia ad congressum mulierum) (Cardano 1663, Vol. I, 5-6, 43-44). Above all, Cardano counts among his most important rules of life that "he wished to care for the elderly and to be with them." (Lib. I, Ch. 23, 15) This is perhaps the reason he dedicated a greater part of his dietetics (De sanitate tuenda, Lib. IV) to gerocomy, the care of the elderly. The same text includes a chapter on his own manner of life in his late sixties (Vol. IV, Ch. 10). Once again, he reports that, up to that age, he had lost twelve teeth, primarily in his lower jaw - adding, this time, that he adapted his diet to match his ability to chew. His morning bread had to be fresh and soft, or soaked in water (Cardano 1663, Vol. VI, 258-259; cf. Schäfer 2003).

In two other texts, Cardano discusses aging from a philosophical point of view. As is typical of his moral philosophy, he attempts "to apply moral laws to the concrete circumstances of [...] life." (Giglioni 2019) Book two of his trialogue Theonoston is devoted to the extension of life (De vita producenda). A nameless citizen seeks advice from a hermit and a philosopher on how to achieve peace of mind (tranquillitas) and a happy life. According to the hermit, old age gives one every reason to sink into tedium, and a long and healthy life is determined, first and foremost, by a person's congenital condition. Nonetheless, it is possible to reach a venerable age provided one recognizes its advantages and uses one's mind to balance out the weaknesses old age typically imposes. The hermit locates such a weakness, once again, in the teeth, which he says will naturally fall out as acrid humors, flowing constantly from the brain, damage and erode their roots. The same applies to the vapor rising from the stomach. The permanent change from cold to hot may have a similar effect (Cardano 1663, Vol. II, 376). Nevertheless, even in the sixteenth century, there were remedies at hand, as demonstrated by the hermit, who rinses his mouth with a mixture of wine and spices before dinner (but recommends doing so only once or twice a month) (Cardano 1663, Vol. II, 382). Another example is provided by the stomach troubles from which almost all elderly people suffer, making it particularly important to start a diet as early as possible in life: one should eat little, but of good quality, and one should have not one but several meals a day. Many more recommendations follow - for instance, about the manner of life of the elderly - with the hermit adopting a surprisingly liberal position, that of "equal variety" (varietas aequalis): people must make a choice based on their physical condition, the season, and their stage of life, but once they do so it should be maintained (Cardano 1663, Vol. II, 389).

In another philosophical text, De utilitate ex adversis capienda, Cardano borrows heavily from Petrarch's famous De remediis utriusque fortunae. Both au- 
thors try to convince their reader to derive benefit from calamity, and argue that "bad old age" can serve as a useful example. Whereas the hermit in Theonoston is an advocate for the final phase of life, Cardano himself begins De utilitate (Lib. II, Ch. 4) with an attack on old age, arguing that there is no greater and at the same time less remediable evil than old age. In addition to illness and physical weakness, Cardano emphasizes the mental and personal failings of the elderly. They are nearly invisible to their relatives, and so shunned by them. Yet there is an escape from this unpleasant situation: Cardano again advises the use of one's reason, which only deteriorates in the final stages of life, along with the senses, some time after the body (compare Aristotle, Rhetoric II, 14). He compares old age to war: one must maneuver in enemy territory, not relying on supplies from one's immediate surroundings, but on reserves stored up in advance. Cardano lists all kinds of possibilities, drawing from his own experience and his practice as a physician. For example, one should sire offspring early, while still fertile. It is also important to keep one's friends. Cardano describes a number of expedients for this: avoiding complaining and talking excessively, and cultivating good table manners. In particular, the elderly persons should be silent while eating, so that particles of food do not fall from their toothless mouths, and so that they do not spit on the person across the table. Oral hygiene should be strictly maintained to avoid bad breath, visible remnants of food, and rotten teeth. From animals, one should take the lesson to fight with the weapons best suited to one's own constitution. One should not use strength or speed, but rather reason and counsel to overcome others and win them over. Cardano also insists on the importance of storing up material resources to provide for the contingencies of old age, and so avoid any potential hardship later on (1663, Vol. II, 50).

Assessing the ethical substance of Cardano's texts, we must recognize that they do not contain ethical principles as we understand them today. We will not find in them any scientific reflections on moral behavior. Nonetheless, he addresses a number of traditional questions in moral philosophy, expressing his view both as a physician and as someone affected by the issues at hand (all these texts were composed after his fifty-fifth birthday).

Cardano's work implies a simple deontology for the elderly: one "should" behave in such-and-such a way simply because it is befitting for a patient or an elderly person. Premodern dietetics is typically normative. Cardano, however, defends a milder form of obligation, and, with the exception of his defense of prudence, we find no elements of a normative virtue ethics. One of his trenchant rules is secundum medicina sine medicina vivere: to live according to the rules of medicine, but without medicine (Theonoston, Lib. II; Cardano 1663, Vol. II, 390). At first sight, this wording applies only to laxatives, a special kind of medicina, 
but it can be generalized to represent Cardano's broader view. Old age has not yet been "medicalized."

Cardano's teleological approach is much more prominent than his deontological one. In Theonoston, the pursuit of happiness (felicitas) is emphasized, and, as a consequence, aches and pains should be avoided: even old age, epitomized by the hermit, can be a happy condition. Without examining the whole of Cardano's philosophy, we can nevertheless conclude that such happiness is, fundamentally, not a eudaemonic, but a hedonistic and pragmatic goal, tailored to the needs of each individual. Old people may interpret happiness differently from young people: Cardano, then, must propose a special "ethics of old age." Occasionally, we encounter a keyword of Stoic philosophy peace of mind (tranquillitas) - as a goal for the elderly, although not exclusively for them.

The title of Cardano's second moral text, De utilitate, exhorts the readers to pursue advantage (utilitas) by conforming to particular ways of behaving. As the example of war makes clear, the author champions a consequentialist utilitarianism (a hundred years before Hobbes!). Although the elderly cannot avoid losing their teeth, in spite of their precautions, they should derive as much benefit from doing so as they can: losing teeth encourages the prudent man to choose the appropriate food, and to keep silent when eating, and the higher goal of retaining his friends keeps him from complaining about his own suffering. When the pursuit of advantage and happiness represents a moral-philosophical aim extending into old age, teeth become relevant - as do the problems they cause.

Nevertheless, Cardano and many of his contemporaries make clear that happiness can only be achieved when timely provisions are made. Preventative measures - not only regarding teeth, but also finances and the care provided by one's children - were a central topic of premodern gerontological medicine, which was almost helpless in therapeutic terms. Virtue is not Cardano's immediate topic. It nonetheless has an indirect bearing on people, by informing them of beneficial behaviors while there is still time for them to be useful. Happiness in old age can only be achieved when one strives for it. To use another of Cardano's phrases, cito senesce: grow old in time, that is, be prepared to the years to come (De sanitate tuenda, Lib. I, Ch. 8; Cardano 1663, Vol. VI, 36).

\section{Paleotti's fruitful old age}

We have a second impressive example of gerontological ideas from a similar time (only a quarter of a century later) and a neighboring area, Rome. But there are substantial differences, as we will see, for our second author was writing in a 
very different cultural context. Gabriele Paleotti (1522-1597) was a Bolognese canonist and an eminent mediator at the Council of Trent. He spent his final years as a cardinal in Rome, where, two years before his death, he published a treatise "On the Good of Old Age" (De bono senectutis) (Prodi 1967, esp. Vol. II, 563-594). The text was probably written on the occasion of the upcoming eightieth birthday of the (later canonized) priest Filippo Neri. Paleotti was a member of his "Congregation of the Oratorio" (Schäfer 2018).

We can already see just how far this cultural setting differed Cardano's. As a cleric, Paleotti had made a distinguished career in the Catholic gerontocracy, and, as a jurist, he had an inherently more positive image of old age (cf. the lively discussion on privileges granted to the elderly in juridical treatises of the time; see Duve 2008, 204-244; Schäfer 2011, 180, 233). Intended as a congratulatory text between clerics, De bono senectutis had to fulfill certain expectations very far from the scepticism advocated by Cardano.

The text nonetheless contains some surprisingly original thoughts. De bono senectutis follows the tradition of texts defending old age (Sigismund 2003; Moog and Schäfer 2008), but it goes far beyond classical model set by Cicero's Cato maior de senectute. Paleotti regarded this text as one of several platforms from which to start a normative discussion of old age. In his first part, he brings up the claims which Cicero had already argued against: that old age impedes the vita activa by sapping bodily strength and draining away sensual pleasure, and that it marks the approach of death. In particular, Paleotti describes the tristitia animi, a mental depression caused by the restrictions and tribulations of old age (cf. Stern and Cassirer 1946). He prescribes medical treatments to counter bodily frailty, and philosophical remedies to counter tristitia (Paleotti 1595, 33-36).

This is where the debate on the bonum senectutis in the main part of the treatise occurs: it is meant to offer the elderly a positive view of this phase of life, despite its adversities. As the second part of the treatise will show, the debate centers not only on defending and comforting the old - something that falls within the consolatory tradition - but also on precisely defining just what aging means.

What exactly do Paleotti and his contemporaries understand by bonum? Paleotti primarily uses an Aristotelian-Thomistic definition, according to which bonum is something that corresponds to its own pattern (forma). For human beings, this means a condition in harmony with the rational (which is humanity's most important characteristic) and thus a goal worth striving for. Therefore, while a good does not have to be "good" in the sense of being enjoyable or pleasing, it must be "reasonable." Paleotti insists that the bonum senectutis also applies to elderly people who are not getting on "well," either physically or mentally - in- 
cluding bed-ridden people (languentes), whom he refers to time and again (1595, 52-56).

Paleotti discusses in detail the various preconditions ("roots") of the bonum senectutis. Because of their listless senses, the elderly are less susceptible to the passions. Their great experience offers resistance to transitory phenomena like beauty, strength, and eloquence. The prudence which results from their experience is unparalleled in younger people. Since prudence and reason (the most important characteristics of a human being) form a whole, Paleotti describes old age as the stage of life which best suits human nature: old age is the "soul of life" (senectus vitae anima appellata; Paleotti 1595, 82). Even meditation on death (meditatio mortis) contributes to the bonum: it not only strengthens the (religious) fear of God, but frees the mind, purifies the conscience, and produces scorn for human matters, sincerity in speech, the desire to help others, ataraxia (animi securitas), and an improvement of life (Paleotti 1595, 82).

The last part of the treatise returns to Paleotti's main topic. He emphasizes his vision of the bonum senectutis, which is not equally immanent in all human beings. This also applies to good old age (bona senectus), which Paleotti connects - as a condition of external happiness - with longevity and physical and mental health. In opposition to this, the philosophical bonum of old age is not a gift of nature but a matter of human will. It is a choice, and, once this choice is made, age turns out to be most favorable for "living a honorable life, cultivating virtue, and refining rational human nature" (bonum senectutis est honeste vivere, virtutes colere, et naturae hominis, quae ratione praedita est, convenienter operari; Paleotti 1595, 165). This short definition of the bonum defines no external conditions, but rather a moral and religious goal: to live in harmony with the purpose which humans possess as rational beings. The "roots" which Paleotti describes give forth fruits (fructus), in terms of our behavior, which can be harvested and enjoyed in old age: under the constant influence of virtue, old age is fertile, like a field ready for the harvest (Paleotti 1595, 211-213). Paleotti distinguishes between fruits which are for God, those for one's neighbors, and those for the elderly themselves. Due to external illness and the decline of their senses, the elderly are no longer susceptible to desires and excess, and tend towards sober-mindedness and virtue. Finally, their long experience counters extreme self-love, for the elderly are aware of their weaknesses and able to realistically assess their abilities. The result is not a gloom but cheerfulness, with the elderly laughing about themselves (Paleotti 1595, $226-227)$.

As already mentioned, Paleotti's normative moral philosophy of old age clearly differs from Cardano's. This is due partly to their professional backgrounds, and partly to the different expectations of their readers. Cardano offers 
a hedonistic, materialistic account of coping with old age, whereas Paleotti, who turns to virtue ethics and voluntarism, tries to subtilize and idealize it as the "soul of human life." But both see old age as a task, and rely on the prescient, prudent mind (ratio) as the crucial mediator in making a difficult situation bearable.

\section{Comparing early modern morality and present ethics of old age}

We move now from premodern morality to the postmodern ethics of old age. We focus on a number of issues heavily discussed over the last twenty years. (A good overview of these is available in Schweda 2018, and Baranzke et al. 2019.) Some are familiar: for example, should old age as a whole to be regarded as a disease, or as good health (Schramme 2009)? Are measures to delay old age justified or not (Maio 2011)? At first sight, these appear to be medical questions, but we can only approach them through philosophical and ethical considerations about the nature of humanity, and through a comprehensive definition of health and disease. Other issues appear relatively new: for instance, the question of inter-generational justice which arises from a shift in working lifetimes and the standard retirement age. Only with the introduction of private and public pension funds in the nineteenth century did people widely begin to enjoy the sort of lifespan which meant they did not have to work until death. The question of "how many old people we can afford” (Boss 2007) is a concern for modern economies, but was rarely posed in premodern times, when the pattern of aging had classic pyramidal form. Furthermore, although their physical capabilities were seen as reduced, old people were in general not regarded as unproductive, for productivity was understood and experienced differently (Metzler 2013, 92-153).

Another topic often treated by the postmodern ethics of old age is largely neglected by Cardano and Paleotti (although it occurs in premodern social-historical sources; Ottaway 2004, 116-126). This is the issue of limited self-determination in old age. In 2010, Claudia Wiesemann, a medical ethicist in Göttingen, defined old age as follows: "In my opinion, we should only speak of old age when people's capability of self-determination is restricted.” (Breuer 2010) For old men in the sixteenth-century cultural elite, the topic did not exist, or was taboo. For demographic reasons, senile dementia was relatively uncommon at the time (Schäfer 2009). With no special provisions for old age, the elderly were required to look after themselves until the end of their lives. The sort of self-responsibility described by Andreas Kruse (2007) was a matter of fact, up 
to and including begging. Cardano and Paleotti also experienced forms of ageism, which they fought either by preparing themselves for "the march through enemy territory," or by giving the situation a radical, religious reinterpretation: "For when I am weak, then I am strong." (2 Cor. 12:9)

Interestingly, in recent times, a basic premise shared by Cardano and Paleotti - that people bear their own responsibility for "successful," "active" aging has emerged in gerontological and ethical debates once again. Van Dyck and Graefe (2012) thus criticize a growing trend towards responsibilization and moralization in modern old-age policies, emphasizing the limits of self-responsibility and the right to live and age in an unplanned way.

In conclusion, looking beyond the details of historical moral philosophy and the present ethics of old age, and the differences and common features between them, what can a historical viewpoint tell us about modern debates? We can propose four theses:

1. Old age is not just an anthropological constant but a cultural construct, formed by both negative and positive images and stereotypes, and influenced by external factors like labor conditions, income, and medical and technical opportunities.

2. Ethical issues regarding the elderly are not independent of time. Rather, they emerge in their respective cultural-historical contexts, and are influenced by the main philosophical and religious themes of the age. Self-determination on the part of the elderly is a twenty-first century topic, rather than a concern of the sixteenth century, and historians see such problems as typical of our time and its paradigms. But this new emphasis on ethical problems does not necessarily indicate that the situation has grown worse in the present - only that such problems have grown more important for us in the age of autonomy.

3. Although Cardano and Paleotti experienced aging in a similar way, at almost the same time, and in close geographic proximity, their different stances reveal that, in spite of the rationality of their arguments, the result of ethical discourse is not neutral or even objective. Rather, it depends on the premises of the discussants and the atmosphere of the respective discourse.

4. Early modern texts show that an ethics of old age must be related to practice. While the disadvantages of aging must be acknowledged, we should also recognize its advantages before we draw our conclusions. The well-intentioned appeal to the elderly to use their minds and make provision will only be helpful for those who live accordingly. From the point of view of modern psychology, it seems essential to encourage positive stereotypes of old age, celebrating it as a bonum, as Paleotti did - or, at least, accepting it as an important part of human life. 


\section{Works cited}

Baranzke, Heike, and H. Güther, L. Luft, Hermann Brandenburg. "Ethik des Alterns." Alternsforschung: Handbuch für Wissenschaft und Praxis. Eds. Karsten Hank, Frank Schulz-Nieswandt, Michael Wagner, and Susanne Zank. Baden Baden: Nomos, 2019. $635-661$.

Boss, Alfred. "Wieviel Alte können wir uns leisten? Volkswirtschaftliche Probleme einer alternden Gesellschaft." Ethik des Alters. Eds. Hans-Jürgen Kaatsch, Hartmut Rosenau, and Werner Theobald. Münster: LIT, 2007. 63-80.

Breuer, Ingeborg. Ethik für eine alternde Welt: Eine Tagung der Uni Greifswald zum demografischen Wandel in Europa und Nordamerika. https://www.deutschlandfunk.de/ ethik-fuer-eine-alternde-welt.1148.de.html?dram:article_id=180633. Deutschlandradio, 2010 (6 September 2021).

Cardano, Girolamo. Opera omnia (10 vols.). Lugduni: Sumptibus Joannis Antonii Huguetan et Marci Antonii Rauaud, 1663.

Duve, Thomas. Sonderrecht in der Frühen Neuzeit: Studien zum ius singulare und den privilegia miserabilum personarum, senum und indorum in Alter und Neuer Welt. Frankfurt am Main: Vittorio Klostermann, 2008.

Giglioni, Guido. "Girolamo [Geronimo] Cardano.” The Stanford Encyclopedia of Philosophy. Ed. Edward N. Zalta. https://plato.stanford.edu/entries/cardano/. Stanford: Metaphysics Research Lab, 2019 (6 September 2021).

Kruse, Andreas. "Chancen und Grenzen der Selbstverantwortung im Alter." "Vom Rechte, das mit uns geboren ist": Aktuelle Probleme des Naturrechts. Eds. Wilfried Härle and Bernhard Vogel. Freiburg: Herder, 2007. 335-377.

Maio, Giovanni. Ed. Altwerden ohne alt zu sein? Ethische Grenzen der Anti-Aging-Medizin. Freiburg: Alber, 2011.

Metzler, Irina. A Social History of Disability in the Middle Ages: Cultural Considerations of Physical Impairment. New York: Routledge, 2013.

Moog, Ferdinand Peter, and Daniel Schäfer. "Joannes Stobaios, 'On Old Age': An Important Source for the History of Gerontology." Journal of the American Geriatrics Society 56 (2008): $354-358$.

Ottaway, Susannah R. The Decline of Life: Old Age in Eighteenth Century England. Cambridge: University Press, 2004.

Paleotti, Gabriele. De bono senectutis. Rome: Ex Typ. Aloysij Zannetti, 1595.

Prodi, Paolo. Il Cardinale Gabriele Paleotti (1522-1597) (2 vols.). Rome: Ed. di Storia e Letteratura, 1967.

Schäfer, Daniel. "Gerodontie aus der Patientenperspektive: Der Fall Girolamo Cardano (um 1565) und seine ethischen Implikationen." Deutsche Zahnärztliche Zeitschrift 58 (2003): 347-349.

Schäfer, Daniel. “Demenz vor Alzheimer? Altern und Gedächtnis in der Frühen Neuzeit.” Medizingeschichte im Rheinland: Beiträge des "Rheinischen Kreises der Medizinhistoriker”. Eds. Dominik Groß and Axel Karenberg. Kassel: Kassel University Press, 2009. 105-124.

Schäfer, Daniel. Old Age and Disease in the Early Modern Medicine. London: Pickering and Chatto, 2011. 
Schäfer, Daniel. "Bonum senectutis - eine frühneuzeitliche Altersutopie.” Altersutopien: Medizinische und gesellschaftliche Zukunftshoffnungen der Lebensphase Alter. Ed. Hans-Jörg Ehni. Frankfurt am Main: Campus, 2018. 97-114.

Schramme, Thomas. “Ist Altern eine Krankheit?" Länger leben? Philosophische und biowissenschaftliche Perspektiven. Eds. Sebastian Knell and Marcel Weber. Frankfurt am Main: Suhrkamp, 2011. 235-263.

Schweda, Mark, Michael Coors, Anika Mitzkat, Larissa Pfaller, Heinz Rüegger, Martina Schmidhuber, Uwe Sperling, and Claudia Bozzaro. "Ethische Aspekte des Alter(n)s im Kontext von Medizin und Gesundheitsversorgung: Problemaufriss und Forschungsperspektiven." Ethik in der Medizin 30.1 (2018): 5-20.

Sigismund, Marcus. Über das Alter: Eine historisch-kritische Analyse der Schriften "Über das Alter / Peri gērōs" von Musonius, Favorinus und luncus. Frankfurt am Main: Peter Lang, 2003.

Siraisi, Nancy G. The Clock and the Mirror: Girolamo Cardano and Renaissance Medicine. Princeton: University Press, 1997.

Stern, Karl, and Thomas Cassirer. "A Gerontological Treatise of the Renaissance: De bono senectutis by Gabriele Paleotti (1522 -1597).” American Journal of Psychiatry 102 (1946): $770-773$.

Van Dyck, Silke, and Stefanie Graefe. "Prävention ohne Ende? Eine soziologische Bestandsaufnahme neuer Alter(n)spolitiken.” Pro Age oder Anti-Aging? Altern im Fokus der modernen Medizin. Eds. Silke Schicktanz and Mark Schweda. Frankfurt am Main: Campus, 2012. 69-85. 